\title{
Comparative studies of national law in the EU harmonized VAT ${ }^{1}$
}

DOI 10.1515/ntaxj-2015-0011

Received Nov 10, 2015; accepted Dec 17, 2015

\section{Introduction}

The aim of this article is to contribute to the theory and methodology of comparative value-added tax (VAT) research, especially when comparative studies are carried out in the EU harmonized field of VAT. There are few fields of law that are harmonized to such a great extent as VAT. ${ }^{2}$ The VAT acts of the Member States have been subject to harmonization for a long time. The first VAT Directives are dated back to $1967 .^{3}$ Soft (non-binding) law harmonization measures are also taken by the OECD. ${ }^{4}$ Furthermore, the VAT acts over the world are similar as such, since a VAT system, in order to be a VAT system, has to have some basic elements, such as right to deduction of input VAT and a general taxation of transactions. The VAT is a young tax that has developed rapidly-the last 65 years. Now, it has spread to approximately 160 countries all over the world. ${ }^{5}$

This article deals with the comparative research method in the field of EU harmonized VAT. The findings in this article regarding the research method may also have

Eleonor Kristoffersson: Professor Doctor, Örebro University, Sweden; Email: eleonor.kristoffersson@oru.se

1 The writing of this article was financed by Vetenskapsrådet and Marianne och Marcus Wallenbergs Stiftelse. Thanks a lot for generous support!

2 The main harmonizing act is Council Directive 2006/112/EC of 28 November 2006 on the common system of value added tax (the VAT Directive).

3 First Council Directive 67/227/EEC of 11 April 1967 on the harmonization of legislation of Member States concerning turnover taxes and Second Council Directive 67/228/EEC of 11 April 1967 on the harmonization of legislation of Member States concerning turnover taxes Structure and procedures for application of the common system of value added tax.

4 See for example OECD international VAT/GST guidelines on place of supply of B2B Services and Intangibles (2014).

5 For a complete list, see e.g. http://gst.customs.gov.my/en/gst/ Pages/gst_ci.aspx, Website access in January 2014. Cf. OECD Observer No 284, Q1 2011, VAT's next half century: Towards a single-rate. relevance for other EU harmonized fields of law. The research gap that this article contributes to, regards basic questions on comparative methodology:

- How should a researcher in VAT decide which jurisdictions to compare?

- Which differences and similarities could a researcher of national VAT law expect to find and what can be the reasons for such differences and similarities?

- Which are the typical problems that may arise?

The general idea upon which this article is based is that legal concepts are differently understood in different legal systems. Some precision of the concepts is lost already in the translation of the harmonizing legal act, in this case, the VAT Directive. For example, supply of goods is called Lieferung, delivery, in the German version of the VAT Directive. ${ }^{6}$ But also when the translation is successful, the understanding of the concepts may differ in different legal and societal environments.

This article does not deal with the comparative method when the EU VAT system is compared with, for example, the Australian, Canadian, South African, or New Zeeland system, but when harmonized laws are compared with each other at the national level. Comparing the EU VAT system with other non-harmonized national VAT systems can be feasible for a general study when the systems as such are in focus. When getting into details, however, it is more appropriate to compare, for example, Germany with New Zeeland, taking the EU VAT system as a starting point, but going down to the same level, namely to national law (other opinion, Rendahl (2008)). There are two reasons for this, both based on the different competences of the EU and the Member States in VAT issues; First, VAT is harmonized by directives, and second, most case law of the European Union Court of Justice (CJEU) is preliminary rulings.

1. When Member States implement directives, they have a certain margin of appreciation, since directives should be implemented in order to achieve

6 Article 14 of the VAT Directive. 
their results. ${ }^{7}$ National VAT acts are hence in many cases more detailed than the directive.

2. Preliminary rulings concern interpretation of the treaties as well as validity and interpretation of acts of the EU institutions. ${ }^{8}$ The application of the law belongs to the competence of the national courts.

Consequently, directives and case law of the CJEU isolated do not fully provide solutions of juridical problems. To get the whole picture, the implementation in national law as well as other national sources such as case law from the national courts have to be taken into consideration.

The starting point of this article is comparative research method and its application on VAT research. After that, the question how to choose jurisdictions for the research is discussed. Thereafter, differences and similarities within the EU VAT system are discussed. The differences and similarities are divided into expected and unexpected differences and similarities. This categorization is to some extent rough, but the idea is to make a difference between those differences and similarities that have to do with harmonization or those that are not. The article ends with some concluding remarks where the research questions are answered.

\section{Comparative research method and its application on VAT research}

\subsection{Legal families}

Comparative law is subject to an extensive legal theory. A traditional view is that a comparative study should be carried out between the parent jurisdictions of the legal families (Zweigert (1972)). In the Germanic legal family, Germany (and not Switzerland or Austria) is the parent jurisdiction. In the Roman legal family, French law (and not Spanish or Italian law) is the parent jurisdiction. In the Anglo-Saxon legal family, British law (and not Indian or Australian law) is the parent jurisdiction (Zweigert and Kötz (1998)). This idea of using legal families as a tool for comparative studies is based upon the assumption that the material of a comparison might be reduced by way of generalization (Rainer (2010)). Comparing all jurisdictions in

7 Article 288 of the Treaty of the Functioning of the European Union (TFEU).

8 Article 267 TFEU. the world would be impossible or at least very difficult. It would therefore simplify the working process of a comparative study if a few representative jurisdictions could be identified.

The classification and division into legal families is challenging. An early classification was made by Esmain in 1900. He suggested a classification into Roman, Germanic, Anglo-Saxon, Slavic, and Islamic legal systems (Esmain (1900)). Only a few decades ago, comparatists, in general, had started to widen their perspective and include other non-European legal systems as a subject of independent study, not only for occasional extra-European excursions (Dölemeyer (2010)). Rainer argues for the existence of two legal traditions within the Western and European legal systems-the Roman law tradition and the common law tradition (Esmain (1900)). This classification leaves room for a third category, mixed legal systems. Mixed legal systems are the ones that do not belong to the Roman or common law tradition, such as the law of Scotland. Also, the Nordic legal systems would be mixed legal systems. Göransson proposes that only at a very high level of generalization and regarding very basic rules, the presumption of similarities of legal systems within one and the same legal family is valid (Göransson (1994)). As soon as the law is studied more in detail, the similarities diminish. Furthermore, the deeper the law is studied, Göransson argues, the riskier it is to assume that similarities depend on the fact that legal systems belong to the same legal family. Similarities might as well have other reasons even though the jurisdictions belong to the same legal family.

Knowledge about legal families and the main characteristics of different legal systems is helpful when jurisdictions are selected for comparative studies. In advanced comparative legal research where the law is studied in detail, randomly selecting parent jurisdictions for comparison because of expected similarities and that the parent jurisdictions should be representative is, however, risky. The reasons for this are that there is no given one and only classification in legal families or legal systems, there are no given parent jurisdictions, and the similarities found within legal families may as well depend on the fact that the two jurisdictions are members of the same legal families as on other reasons. In my opinion, legal family is a too rough tool to be used for the selection of jurisdictions in most comparative studies.

\subsection{Different approaches to comparative law}

When a comparative study is carried out, it is often held that the functional approach should be applied (Zweigert 
(1972); Gunnerstad and Ingvarsson (1997); Avi-Yonah et al. (2009)). This means that, in respect of deciding which questions to answer, the researcher should not focus on rules in a foreign legal system, but on the problems that the rules are intended to solve. For example, a transaction may be VAT-free for several reasons, it may be out of the scope of VAT, it may be exempt from VAT, or it may be supplied or acquired abroad. If a researcher of VAT would only study if the transaction was exempt from VAT, the researcher would not get the answer to the question whether the actual transaction was subject to VAT or not-which would be interesting out of a comparative perspective. The research questions should be formulated in a way that they aim at catching the complexity of a legal system (Göransson (1994)). Comparing the VAT treatment of the insurance sector in several Member States is far more fruitful than comparing the exemption for insurance services.

The functional approach is, however, not the only possible approach to comparative law. The economic approach goes further than the functional approach in the sense that it does not only deal with which functions laws and institutions fulfill, but also ask which laws and institutions that fulfill the functions in the most efficient way. When the economic approach is applied, benchmarks are often set in order to concretize economic efficiency. The economic approach tends to end up in identifying best practices or best solutions based on an economic analysis (Avi-Yonah et al. (2009)). ${ }^{9}$

The cultural approach is based on the idea, that law is part of a broader cultural phenomenon. In each culture, there are unique elements such as values, traditions, and beliefs. If the cultural approach is applied strictly, it is in conflict with the functional approach. Due to each legal system's uniqueness, there are few similarities in social problems and legal solutions (Avi-Yonah et al. (2009)). Consequently, under this view, identifying the same problem and searching for legal solutions thereof result in comparing the incomparable.

In my opinion, the functional approach is relevant when identifying what to compare in foreign law, since it in the field of VAT, it is possible to identify similar transactions of goods or services and compare the VAT effects thereof. The strict cultural approach is characterized by a scent of nationalism, which rests on the idea that national boarders create different cultures. Within a country, there

9 As an example of a comparative study in tax law, applying the economic approach, see Hambre (2015). Tax Confidentiality. A Comparative Study and Impact Assessment of Global Interest. Örebro: Örebro Studies in Law 6. Örebro University. are many different cultures. This does not only apply to cultures in general, but also to legal cultures. Furthermore, as long as a national border is not closed, the cultures on both sides of the border tend to be similar. During the research and when the results are analyzed, however, elements of the cultural approach should be taken into consideration, since culture is closely linked to law. Depending on the aim of the study, an economic approach can be added.

\subsection{Analyzing similarities and differences and using the result}

A comparative study cannot just aim at identifying similarities and differences (Cornell (2015)). Both similarities and differences have to be analyzed in order to understand the reasons behind them (Göransson (1994)). Such an analysis should not be carried out without understanding the societal and historical context of the provisions. In this step of the comparative study, it is often helpful if the quality of the study is assured by native lawyers.

When the similarities and differences are explained, the last step in the comparative study is to use the result (Göransson (1994)). It could be used for suggesting changes of law, or to find the most appropriate legal solution, based on certain benchmarks-of a particular problem. In a wider sense, it could be used for the widening of knowledge about the national legal system as well as for better understanding of foreign legal systems (Rainer (2010)). If the functional approach is applied strictly, the aim of the study should be to find the rules with the most appropriate function in relation to the problem (Gunnerstad and Ingvarsson (1997)). In harmonized fields of law, such as VAT law, the implementation and application of a directive in other Member States can offer guidance regarding both possible ways of interpreting the directive and how the directive could be implemented (Göransson (1994)). From a practical point of view, comparative studies are highly relevant in cross-border trade (Göransson (1994)).

\subsection{Applying the comparative research method on EU VAT law}

In the field of comparative VAT law, little is written about theory and methodology. The most well-known text book in comparative tax law, in general, is Thourony, Comparative Tax Law Thuronyi (2003)). This book, however, fo- 
cuses much more on describing different tax systems of the world, than with methodological issues.

In EU VAT law, there is little research done regarding how to carry out a comparative study at the national level. The standard work, Shenk/Oldman (2007, Value Added Tax-A comparative approach) offers a comparative presentation, but it does not particularly deal with methodical issues. There are also conference volumes with a large quantity of comparative material on VAT, but where the comparative method is not dealt with (See ?Lang and Lejune (2014)).

The reason for the apparent lack of any research on the comparative method in VAT research is most likely that the VAT and GST (general sales tax) systems around the world are fairly similar. From a methodological point of view, it is a relatively simple task to identify the provisions regulating, for example, the right of deduction in two different VAT systems and compare them. Likewise, it is to find out whether internal transactions of goods and services are taxed when they are supplied cross-border from a head office to a branch. Thus, it is probably assumed that there are not any certain methodological issues that should be taken into consideration. However, in my opinion, this is a flawed view. As mentioned above, the EU VAT is harmonized by directives that have to be transformed into national law. As long as the result of the directive is achieved, the Member States are free to choose how to implement the directive. This means that the VAT acts of the different Member States differ to a fairly large extent from each other.

When examining the history of the VAT acts in different EU Member States, one can often find that the Member States have maintained some of the legislation that they had before the common EU VAT entered into force. Interestingly, the structure of some VAT acts and some of the provisions in them can be traced back to the time before VAT was introduced. For example, there are provisions in the Swedish VAT act ${ }^{10}$ that stems from the omsen, which was the general sales tax that was applied before VAT (SW: momsen) was introduced in 1969 (See Forssén (2013)). ${ }^{11}$ The general structure of the Austrian VAT act ${ }^{12}$ can be traced to the German sales tax system introduced during the German occupation in World War II. ${ }^{13}$

10 Mervärdesskattelagen (1994:200), the Swedish VAT Act (SVATA). 11 Eg Chap. 6 Sec. 2 SVATA.

12 Umsatzsteuergesetz, UStG 1994, the Austrian VAT Act (AVATA). 13 Reichsteuerblatt, RStBl 1938, 425 and Weitergeltungsgesetz vom 1.5.1945, Steuergesetzblatt, StGBl 12.

\section{The selection of countries for the comparison}

When making a comparative study in the field of EU VAT law, the starting point should be the common legal basis, which is binding EU law (directives, regulations, and decisions) and the interpretation thereof by the CJEU. Since the CJEU has developed its case law for many years, and the national courts of last instance are obliged to refer questions of interpretation to the $\mathrm{CJEU},{ }^{14}$ there are hundreds of VAT cases. To describe, analyze, and understand EU law is therefore an important and time-consuming piece of work. This might be one explanation for why some researchers choose to stay at the EU level and not go further to the national VAT law (see e.g. Rendahl (2008)). In the article Holding complexity: analysing the CJEU's VAT case law as a network, Knops and Schaper (2014) propose a new method for analyzing CJEU case law, by using data-driven modeling to build a case-to-case network. Their method is one way of dealing with the large number of cases of the CJEU.

When EU VAT law has been analyzed, the next step is to select jurisdictions for the comparison. One of the most difficult parts of a comparative study is to get knowledge about foreign law (Göransson 1995). This is difficult because understanding the law requires not only knowledge about legal sources and the legal system, but also understanding about the society in which the law operates (Göransson 1995). For this reason, it is far easier to make a comparative study in a country where the researcher knows the language and has knowledge and experience of the legal system or where the researcher has established contacts than in any other country. Nevertheless, the selection of countries should be motivated by other than practical considerations. How the jurisdictions are selected should, in my opinion, depend on the aim with the study. Following issues could be addressed in relation with the aim of the study.

- Does the study aim at giving information to new Member States of how the VAT Directives and the case law of the CJEU are understood by the Member States that have been members of the EU for a longer time?

For example, when Sweden, Finland, and Austria became members of the EU in 1995, it was fruitful to make a comparison with jurisdictions in Member States, which had been members of the EU since the beginning, and

14 Article 267 TFEU. 
where there was a lot of national case law as well as legal literature on VAT (e.g. Alhager (2001)). The same applies today for new Member States, such as Rumania, Croatia, and Hungary. For new Member States, EU VAT law is law out of context (Watson (2008)). EU VAT law does not come from the inside country but from outside; from the EU. Therefore the history, culture, and society are not reflected in the law. This increases the risk of different understanding of EU harmonized law of the different Member States compared with national law of national courts.

- Does the study aim at examining how the EU VAT law is implemented, applied, and understood in the jurisdictions that affect most taxpayers?

In this case, large countries should be chosen, such as the UK, France, Spain, Italy, Germany, and Poland.

- Does the study aim at examining how different legal systems understand and deal with EU VAT law?

In this case, for example, UK for the common law system, a representative for the continental legal system, such as Germany or France, and a representative for the Nordic mixed legal system could be selected. In such a situation, it is relevant to consider parent legal systems, since these might set good examples for the different legal systems.

- Does the study aim at revealing differences in the system that is supposed to be mainly one and the same?

This approach requires pre-studies. For this approach, any jurisdiction within the EU could be selected. The researcher can also pick examples on inconsistencies in different jurisdictions. If, for example, Austria taxes the rental of apartments for living, ${ }^{15}$ but no other Member State does, Austria would be an interesting jurisdiction to compare the implementation of the exemptions on the field of real estate. Pre-studies can be carried out in different ways, for example, by arranging comparative seminars and conferences, by literature studies, data base studies, interview studies, etc.

Another aim of a comparative study could be to compare the VAT acts of current EU members and potential applicants (Rainer (2010)). This would, however, only partly be a comparative study of EU VAT.

The decision on how many jurisdictions to include in the study depends on several factors. Again, the aim of the comparison is important. Should the description of VAT law in the different jurisdictions be complete, or should it just give examples? If the aim is to give a complete description, the number of jurisdictions should be limited to one or only a few countries if the research covers many questions. If the scope of the study is narrow, more jurisdictions can be included in the study. An example is Cappacioli's study on how bitcoin is treated for VAT purposes. Since the scope of the study was narrow, Cappacioli could include five countries, even though the article where the results are published is only two pages (Cappacioli (2014)).

Wiman proposes that when considering how many jurisdictions that should be included in a comparative study, one should make a calculation of how many questions that should be dealt with times number of countries times estimated number of pages for each question and country (Wiman (2005)).

Questions $\times$ jurisdictions $\times$ pages for each question and jurisdiction

Such a calculation can be useful also when making a comparative study in a harmonized field of law such as VAT. It is easy to underestimate the workload and the size of a comparative study including many jurisdictions.

\section{Differences and similarities}

\subsection{General}

The VAT Directive is a harmonizing directive, not a minimum directive. In spite of this, there is some discretion for the Member States when implementing the directive. Some provisions are not mandatory to implement, ${ }^{16}$ the Member States may retain some national provisions that they had when they became members of the $\mathrm{EU}^{17}$ and the Member States may have negotiated exceptions from the VAT Directive in their accession treaties. In this section, different kinds of differences are discussed.

In a harmonized field of law, most similarities are expected. The similarities are there because of the harmonization. There are, however, similarities depending on other reasons. Unexpected similarities occur when the national VAT acts diverge from the directive and the divergences are the same in two or more Member States. Such similarities are interesting to analyze further. Since most similarities are expected, this section focuses on differences.

16 For example article 11 of the VAT Directive regarding VAT groups. 17 See article 176 of the VAT Directive.

15 Sec. 10 (2) 4 a AVATA. 
The structure of the analysis of differences is the following:

1. Differences because of the discretion of the Member States:

a. Provisions in the VAT Directive that are not compulsory to implement

b. Exclusions from the VAT Directive that the Member States are allowed to keep

c. Exceptions due to the accession treaties

2. Differences within the harmonized field: EU VAT law is not applied and interpreted in the same way by the 28 different Member States

a. Legal transplants

b. Legal formants

c. Differences in how Member States understand EU law

\subsection{Differences because of the discretion of the Member States-expected differences}

\subsubsection{Provisions in the VAT Directive that are not compulsory to implement}

As mentioned above, several provisions in the VAT Directive are not compulsory to implement. This applies, for example, to VAT groups (article 11), transfer of a business or part of a business (article 19 and 29) and the option to tax financial services, supplies of buildings and land under certain conditions as well as the letting and leasing of immovable property for business purposes (article 135). Reduced tax rates are also optional. When differences have been identified, it is interesting to find out why the Member States have chosen different solutions. Changes in implementing the optional provisions are also interesting. Sweden's VAT group provisions can serve as an example.

Sweden became a member of the EU 1 January 1995. By then, Sweden chose not to implement what now is article 11 of the VAT Directive (Article 4.4 (2) of the Sixth Directive) regarding VAT groups (consolidation of groups of companies for VAT purposes). One explanation to this is that Sweden does not consolidate groups of companies for income tax purposes. Instead, group contributions are used to equalize profit and loss in income tax. Soon after the EU membership the Swedish groups of companies with mixed activities-taxable and non-taxable activities-and hence a limited right to deduct input VAT on internal supplies got difficulties in their competition with correspond- ing companies in other Member States, since the Swedish groups had to bear substantive VAT costs. The lines of business where the problems were most severe were the insurance and financial sectors. In order to mitigate the problems, Sweden implemented VAT group rules for the insurance and financial sectors by 1 July $1998 .{ }^{18}$ The reason for not implementing general VAT group rules that would apply on all groups of companies regardless of business line was that general VAT groups would be too costly for the state. Last year, the right wing government proposed to abolish the VAT groups. The new social democrat government, however, decided on 15 April 2015 to retain the VAT groups since an abolishment would be too burdensome for regional banks (Sparbanker). ${ }^{19} \mathrm{~A}$ late introduction of VAT groups, a narrow scope of VAT groups, and the discussion of the abolishment of VAT groups are interesting features of Swedish national VAT law in this field.

\subsubsection{Exclusions from the VAT Directive that the Member States may retain}

Under article 176 (2) of the VAT Directive, Member States may, as mentioned above, retain all the exclusions from the right to deduct input VAT provided for under their national laws on 1 January 1979 or, in the case of the Member States that acceded to the $\mathrm{EC}^{20}$ or EU after that date, on the date of their accession. In practice, the Member States have retained several exclusions from the right to deduction. The exclusions often regard, for example, representation costs, cars and motorbikes and immovable property that is suitable to use for private purposes. ${ }^{21}$

Even though these differences are expected, they are interesting to analyze. When the VAT is harmonized within the EU, one would expect that such a central part of the VAT system as the right of deduction should be harmonized. The exclusions may not be extended after the time of the accession of the Member States. They may not be general in that sense that they change the general principle in article 168 of the VAT Directive, that in so far as the goods and services are used for the purposes of the taxed transactions of a taxable person, the taxable persons shall be entitled to deduct the input VAT. Research questions regarding this provision that could be asked and answered within a comparative study are:

18 Chapter 6 a SVATA, 1994:200, changed by SFS 1998:346.

19 Spring budget for 2015 (Prop. 2014/15:100) section 5.7.

20 European Community.

21 See for example Chapter 8 Section 9 and 15-16 SVATA. 
- Which exclusions from the right of deduction have the Member States introduced?

- Why have the Member States chosen to keep these exclusions?

- How have those exclusions changed over time, have they become narrower (allowed) or wider (not allowed)?

- How general or specific are the exclusions?

There are several other exclusions from the VAT directive that the Member States are allowed to retain. General derogations for all Member States that were EU Members on 1 January 1978 are found in article $370-374$ of the VAT Directive. Furthermore, there are derogations that are allowed after authorization in article 394-395 of the VAT Directive.

\subsubsection{Derogations due to the accession treaties}

When new members enter the EU, it is common that the Member States negotiate derogations from the VAT Directive. Such an example is $\S 10$ (2) Nr. 4 b in the Austrian VAT Act $^{22}$ that provides for a reduced tax rate of $10 \%$ on letting and leasing of immovable property for private purposes. Derogations for states that acceded to the EU after 1 January 1978 are listed in article 375-390 c of the VAT Directive.

\subsubsection{Methodological issues regarding differences because of the discretion of the Member States}

The three categories of differences because of the discretion of the Member States are expected. The most expected differences of the three are the ones depending on that some provisions of the VAT Directive are optional for the Member States to implement. It cannot be assumed that every Member State has implemented the optional rules. When optional rules are implemented, the Member State has a certain margin of appreciation. ${ }^{23}$ Consequently, the optional rules may have been implemented in different ways in different Member States.

It can also be expected that especially Member States that have entered the EU rather recently have maintained

22 Umsatzsteuergesetz, UStG 1994.

23 See C-480/10 European Commission v Kingdom of Sweden, ECLI:EU:C:2013:263 which shows that the Member States have a certain margin of appreciation when they implement optional rules, in this case VAT group rules. some exclusions from the right of deduction under article 176 of the VAT Directive. For the original Member States, some exclusions from the right to deduct input VAT may have played out their role.

Derogations due to the accession treaties were previously difficult to find. Since they nowadays are included in the VAT Directive, this does not apply anymore. It is, however, not necessarily the case that the Member States actually make use of the derogations. To find this out, it is necessary to examine national VAT law.

\subsection{Differences within the harmonized field-unexpected differences}

\subsubsection{General remarks}

When there is no support in EU law for differences between the VAT laws of the Member States, it would be expected that the VAT laws would achieve the same result. The same kind of persons would be taxable persons, the same kind of transactions would be taxable transactions, the same kind of transactions would be exempted, and the requirements for deduction would be the same. When VAT is studied in detail, this is not always the case. For example, if a temperance society runs a cinema in Sweden, the sale of tickets would not be subject to VAT. ${ }^{24}$ In Austria, the tickets would be subject to $13 \%$ VAT. ${ }^{25}$

One reason for differences is built into the procedural system of the EU. Under article $267 \mathrm{TFEU}^{26}$ regarding preliminary rulings, any national court or tribunal may and any national court against whose decisions there is no judicial remedy under national law shall bring the matter before the CJEU if it considers that a decision on the question is necessary to enable it to give judgment. This means that only the last instance is obliged to submit questions of interpretation to the CJEU. Since a leave to appeal is often needed to the last instance, lower instances without any obligation to submit the questions of interpretation to the $\mathrm{EU}$, are often the last instance. Even if a case reaches the last instance, it is up to the court to decide whether a preliminary ruling is needed or not. Hence, different interpretations of EU VAT law can be observed in both lower and the highest court instances, when case law is compared.

Furthermore, as mentioned above, preliminary rulings under article 267 regard interpretation and not appli-

\footnotetext{
24 Chap. 4 Sec. 8 SVATA.

25 Sec. 10 AVATA.

26 Treaty of the Functioning of the European Union.
} 
cation of the law. To apply the law is always a matter for the national court. It is difficult to draw a sharp line between application and interpretation, but it can be concluded that even if the interpretation is the same, the application may differ.

The only procedural way to deal with different application in different Member States is that the commission (or another Member State) brings a matter of non-fulfillment of the obligations laid down in the treaty before the CJEU. The procedure for such an action is laid down in article 258 and 259 TFEU.

The procedural reasons are practical explanations on why differences may occur. If neither the interpretation nor the application of a provision in the VAT Directive is clear, and not all cases that should need to be clarified reach the CJEU, differences may occur.

\subsubsection{Legal transplants}

The theory of legal transplants, developed by Watson (1974), launches that society's laws do not usually develop as a logical outgrowth of its own experience. Instead, the laws of one society are primarily borrowed from other societies. Consequently, most law operates in a society very different from the one for which it was originally created. This borrowing is what he calls legal transplants (Watson (2000)). Since the VAT Directive is developed by the Member States as a collective, it is a farrago of influences from the different Member States that shall be implemented in each Member State. Therefore, the theory of legal transplants is worth some attention in this article.

Watson writes about legal transplants:

"Legal borrowing I would equate with the notion of legal transplants. I find it difficult to imagine that anyone would deny that legal borrowing is of enormous importance in legal development. Likewise I find it hard to imagine that anyone would believe that the borrowed rule would operate in exactly the way it did in its other home. What I think is significant in the context of this article is not the identity of interpretation but the fact that identity of rule does lead to much greater similarity between the two systems. In no way should one neglect the differences. They are also fundamental in understanding how, why and when law changes, the direction of legal change, and how law develops in the society in which it operates"

Watson (2000)

An interesting notion in the quotation above when discussing unexpected differences in the harmonized field of VAT is "Likewise I find it hard to imagine that anyone would believe that the borrowed rule would operate in ex- actly the way it did in its other home”. If a legal rule is taken from somewhere and is placed somewhere else, the outcome will not be the same. I suggest that the same applies when a directive is implemented in different jurisdictions, and I even suggest that the same applies for regulations that shall not be implemented, but have general application. ${ }^{27}$

Even before Watson did his research on legal transplants, it was a well-known phenomenon that the content of the law changed depending on in which legal culture and in which society it operated. Already in 1928, Pound discussed what had happened with the English and French law that once was transferred to the US (Pound (1928)). What can be seen in Pounds analysis is the importance of the perspective of time as well as of the societal influences:

\begin{abstract}
"According to the American legal theory, the colonists brought the common law of England with them as part of their inheritance. But, as often has happened, the law in the books and the law in action prove to be quite different. The charters usually provided that colonial legislation should not be repugnant to the common law of England, and colonial statutes were sometimes disallowed by the Privy Council on this ground. In the everyday administration of justice, however, there was for a long time little or no need of so advanced and technical a body of precepts as the seventeenth-century English law. According to legal theory, Michigan, Illinois and Wisconsin were once governed by the Custom of Paris. Yet, French law has not left the slightest mark upon the actual law of those states.”
\end{abstract}

Pound (1928)

When the society changes-as the US society did after the American Civil War and in the beginning of last century due to a massive industrial growth-the law had to be understood differently. Pound suggests: "If we are to proceed wisely in creative juristic activity in the complex society of today, we must study scientifically the legal materials of the whole world. Thus we shall know better the possibilities of our own legal materials, which have come down to us from the last century." (Pound (1928))

Pound comments on the difference between law in the books and law in action, and that the law in action differs from the law in the books, due to the situation in the surrounding society (Pound (1928)). This difference stems from Justinians book Institutes from 30 December 533 (Watson (2008)). Watson assumes that the distinction between the law in the books and the law in action is valid, but that the concept of the law in the books must be subdivided

27 Article 288 TFEU. 
into two categories; first, law that reflects the conditions, needs, and desires of the society in which it operates; and second, borrowed law, which does not, but must hence not be unsatisfactory (Watson (2008)).

The theory of legal transplants has been heavily criticized. Legrand, for example, suggests that it is pointless to discuss legal transplants, since the only thing that can be transferred to one country from another is rules (Legrand (1997)). Rules are transferred from one country to another, and the rules are often not defined. The concept of legal is hence, according to Legrand, reduced to rules. The main criticism, however, is regarding how law changes-if the law changes because of a massive borrowing of rules (so Watson) or if the law changes due to societal factors (so Legrand). This could be of some relevance for harmonized EU VAT law, when analyzing the original provisions and later changes in the VAT Directive. Do they come from the national laws of the Member States or are they results of the demands of the surroundings society, for example, a well-functioning common market or an efficient tax administration? For the topic of this article, focusing on national VAT law in the Member States, it is not of greater relevance. Legrand's view results in another comparative approach than the one of Watson. The aim of comparative studies should therefore not be to find analogies and parallels, but on the contrary, to find individuality of developments. The causes of the specific characteristics should then be analyzed.

Comparative law researchers criticizing the theory of legal transplants, such as Legrand, share the view that the content of the law-or of the rules-become different depending on in which context they operate. Legrand takes the following example:

"In enacting a rule for the reasons they do and in the way they do, as a product of the way they think, with the hopes they have, in enacting a particular rule (and not others), the French, for example, are not just doing that: they are also doing something typically French and are thus alluding to a modality of legal experience that is intrinsically theirs. In this sense, because it communicates the French sensibility to law, the rule can serve as a focus of inquiry into legal Frenchness and into Frenchness tout court. It cannot be regarded only as a rule in terms of a bare propositional statement. There is more to ruleness than a series of inscribed words which is to say that a rule is not identical to the inscribed words."

Legrand (1997)

Due to the importance of the societal factors, Legrand's opinion is that, at best, what can be displaced from one jurisdiction to another is, literally, a meaningless form of words. In his opinion, to claim more is to claim too much.
His conclusion is that in any meaningful sense of the term, legal transplants cannot happen (Legrand (1997)).

In VAT, the directive is the set of rules that through implementation is transformed into national law. Different from when, for example, the German Bundes Gesetzbuch (BGB) was adopted by Estonia, in EU law, the CJEU provides a vehicle for common interpretation. Therefore, it does not apply that just words are transferred. Most interpretation and application of VAT rules are, however, not done by the CJEU, but by national courts.

The implementation of the directive as such enables an adaption to national circumstances, since it is only binding as to the result to be achieved. ${ }^{28}$ Already at the implementation stage, some of the harmonization is lost. Even though the VAT is harmonized and the CJEU has jurisdiction over the interpretation of the directive, VAT law including the implementation and application of the law cannot be the same in all Member States. This depends on that the law operates in an actual context and that the content of the law is to a great extent given of individuals with a certain national common legal understanding.

Even within one and the same jurisdiction, law is not always consistently applied (Rizal Salim (2009)). The fact that different administrative courts of first instance or different districts courts interpret and apply the law in different ways is dealt with by having supreme administrative courts and supreme courts that can clarify how the law should be understood. In my opinion, this is not a failure, but a part of the legal system. This is how law works in practice. As long as the laws are general and not casuistic, there will always be different understanding of their content. Hence, the imperfection of the EU VAT system is a part of the system. From a practical point of view, the imperfections may cause problems. Different classification of the same goods or services in different Member States may lead to double taxation or non-taxation in cross-border trade; it may result in distortion of competition because one Member State deems a supply exempt whereas another Member State does not or because of different understanding on limitations in the right of deduction of input VAT.

\subsubsection{Legal formants}

Also, the theory of legal formants in comparative law can add some knowledge to differences within the field of harmonized law. The theory was developed by Sacco (1991).

28 Article 288 TFEU. 
Legal formants are everything that constitutes the law, not only formal rules and a hierarchy of relevant sources. Sacco illustrates the importance of legal formants with the following example:

\begin{abstract}
"Suppose we were to study how two different legal systems resolved a problem, for example, the problem of liability of the manufacturer of defective products or damage caused to someone other than the direct purchaser. Suppose we found that the statutes of the two legal systems were the same. We might find either that the judges of both systems applied the same rules or that they applied different ones. If they applied the same rules, the reason might be that these rules actually were consequences of the statutes. If, however, they applied different rules, it would be clear that the statutes alone were not responsible for the rules followed by the judges. We could then ask what, if not the statute, might be influencing the judges. A comparative method can thus provide a check on the claim of jurists within a legal system that their method rests only on logic and deduction.”
\end{abstract}

Sacco (1991)

An important aim of comparative studies is hence to destroy "scientific" methods of legal reasoning, showing that a judicial decision may announce one rule, even though the judge is following another one (Sacco (1991)). The legal formants of a legal system are not necessarily all of legal character. Canon law can hardly be explained without the notion of God. Former Soviet law is difficult to explain without the ideas taken from Engels, Marx, and Lenin (Sacco (1991)). The legal formants may differ from court to court and from judge to judge within one and the same legal system (Sacco (1991)). A judge appointed from an academic position might stress on scholarly opinions more than a judge with a background as a legal practitioner (Bussani (1997)).

Just like the theory of legal transplants, the theory of legal formants departs from the idea that what looks the same does not turn out the same in reality, due to complexity in what constitutes a legal system and the content of the law. The legal formants in a system are more than formal law and other relevant sources dealt with in a certain manner. The potential of that the law in practice turns out exactly the same in all Member States after a harmonization of the law seems to be fairly low. ${ }^{29}$

29 In private law, the common core approach has been put forwards as a vehicle of harmonization. An aim of comparative studies is, when applying the common core approach, to identify similarities in nonharmonized law and propose harmonization due to these similarities. See Bussani (1997, 339-356).

\subsubsection{Differences in how Member States understand EU VAT law}

As mentioned above, Cappacioli has made a comparative study on the VAT treatment of bitcoin..$^{30}$ Bitcoin is an unregulated means of payment used for payments of goods and services.

Under article 2 (d) of the VAT Directive, the supply of services for consideration within the territory of a Member State by a taxable person acting as such shall be subject to VAT. A supply of services is any transaction that does not constitute a supply of goods. ${ }^{31}$ Financial assets, such as bitcoin, are considered to be services under the VAT Directive.

Services may be exempt from VAT. There are some exemptions in the VAT Directive that could apply on the exchange of bitcoin, article $135.1 \mathrm{~d}$ and e of the VAT Directive:

(d) transactions, including negotiation, concerning deposit and current accounts, payments, transfers, debts, cheques, and including debt collection;

(e) transactions, including negotiation, concerning currency, bank notes, and coins used as legal tender, with the exception of collectors' items, that is to say, gold, silver, or other metal coins, or bank notes that are not normally used as legal tender or coins of numismatic interest.

The VAT treatment of bitcoin was recently clarified by the CJEU in case Hedqvist. ${ }^{32}$ The case deals with exchange of bitcoin into traditional currency and the opposite. The CJEU stated that the exchange of bitcoin was exempt from VAT under article $135.1 \mathrm{e}$ of the VAT Directive. Before that, the taxation or non-taxation of bitcoin exchange differed between the Member States.

In Estonia and Poland, transactions with bitcoin were not exempt from VAT due to a strict interpretation of article 135.1. The exemptions in article 135 shall, according to the case law of the CJEU, be strictly interpreted, and the transactions with bitcoin or similar unofficial means of payment are not expressively exempted in article 135.1 or elsewhere.

In Sweden, the Board of Advanced Rulings ${ }^{33}$ deemed the exchange of bitcoin as a transaction concerning currency under article 135.1 e of the VAT Directive. This is the case that was referred to the CJEU. One reason for

30 The facts in this section 4.3.4 are based on Cappacioli, Stefan. 2014. "VAT and Bitcoin". EC Tax Review [2]: 361-362.

31 Article 24 of the VAT Directive.

32 C-264/14 Hedqvist ECLI:EU:C:2015:718.

33 Skatterättsnämnden. 
that bitcoin was considered to be a currency was that it had the same function as a currency. This seems to be an expression of the problem-orientated approach to settle disputes, which is characteristic for the Nordic countries. When using this approach, the court is seeking to find a reasonable solution by balancing different interests against each other. A Swedish court would seldom settle a dispute solely by defining a concept in an abstract way and then apply the concept on the facts of the case.

In Germany and the UK, transactions with bitcoin were exempted under article $135.1 \mathrm{~d}$. An alternative reason for tax-freeness was in the UK that the transactions do not constitute economic activities.

This example shows that even where the VAT Directive is very detailed, different interpretations and applications may occur. The problems with the bitcoin case occurred due to a change in the society. When the exemptions in article 135.1 regarding financial activities were written, the bitcoin did not exist. For economical, business, and academic interests, it is of great value to reveal such differences.

From an academic point of view, different understanding of harmonized law proofs that rules are unclear and hence difficult for taxpayers and the tax administrations to deal with. In tax law, this may lead to legal uncertainty.

From an economic point of view. the main reason for harmonizing the VAT rules is to achieve a well-functioning common market. If the treatment is still after the harmonization different, measures might have to be taken for further harmonization.

From a business point of view, the inconsistencies may be used for international tax planning. The taxpayers are more likely to carry out their business in a jurisdiction where transactions with bitcoin are not taxed than where they are subject to VAT.

\section{Conclusions}

In the beginning of this article, I formulated some questions that should be dealt with. The first question was:

- How should a researcher in VAT decide which jurisdictions to compare?

The answer to this question is that jurisdictions that fit the aim of the study should be chosen. New Member State-old Member State, Member States with interesting and different solutions or Member States with different legal cultures could be included in comparative studies. To choose the parent jurisdictions is seldom necessary. The reason to do that would be if the aim is to study large jurisdictions or to study how the VAT Directive is implemented and understood in different legal cultures. It is, however, not necessary to choose the parent jurisdictions for any of these reasons.

- Which differences and similarities could a researcher of national VAT law expect to find and what can be the reasons for such differences and similarities?

In a harmonized field of law, it could be expected that the national laws are similar. When the laws are harmonized by directives, it cannot be expected that they are exactly the same, since directives are only binding to the result. The VAT Directive opens up for several differences. Some provisions are optional to implement and the Member States are allowed to retain some exclusions from the VAT Directive that they had when they become members of the EU. The accession treaties may contain further exclusions.

As shown in the discussion of the theories of legal transplants and legal formants, and the example of VAT treatment of bitcoin, even if it would be reasonable to expect the law to be the same in all Member States, it cannot be expected that the law operates in exactly the same way in all Member States. This depends on linguistic, cultural, personal, and societal factors, as well as in which legal system the law is. Consequently, also, in the fully harmonized field of VAT law, differences are part of the system.

- Which are the typical problems that may arise?

The main problem that may arise when doing a comparative study in a harmonized field of law, such as VAT, is to expect more similarities than there are. At a first glance, the VAT acts may look very similar. It is therefore important to examine foreign law in detail to find the real differences and similarities.

Another problem is that it might be difficult to understand foreign law completely, even if it is similar to the law in the home country. It is therefore to recommend to quality assure the results by consulting relevant competence in the foreign country, for example, by presenting the result at a scientific seminar.

In comparison with other taxes, VAT is easy to compare with other jurisdictions due to its consistent system. Hence, VAT is, in my opinion, very suitable for comparative studies. 


\section{References}

Alhager, Eleonor. 2001. Mervärdesskatt vid omstruktureringar. Uppsala. lustus förlag

Avi-Yonah, Reuven, Inbar, Guy, Marian, Omri, Mello, Linneu. 2009. “Comparative Law: Theory and Practice". Bulletin for International Taxation [1]: 183-5.

Bussani, Mauro, Mattei, Ugo. 1997. "The Common Core Approach to European Private Law". Columbia Journal of European Law [3]: 339-56.

Cappacioli, Stefan. 2014. "VAT and Bitcoin". EC Tax Review 23 [2]: 361-2.

Cornell, Anna Jonsson. 2015. Komparativ konstitutionell rätt (2nd edition). Uppsala: lustus förlag

Dölemeyer, Barbara. 2010. "Legal Families", European History Online, 2010-12-03. ieg-ego.eu/en/threads/crossroads/legalfamilies.

Esmein, Adhémar.1900. "Le Droit comparé et l'enseignement du droit", in: Nouvelle revue historique de droit français et étranger [24]: 489-98

Forssén, Björn. 2013. Skatt och betalningsskyldighet för moms i enkla bolag och partrederier (1 $1^{\text {st }}$ edition). Örebro: Örebro Studies in Law 4. Örebro University

Gunnerstad Annelie, Ingvarsson, Torbjörn. 1997. “Den komparativa rätten - värd en omväg”. Svensk juristtidning. [2]: 152-71

Göransson, Ulf. 1994. "Komparativa reflexioner. Några metodproblem vid rättsjämförande studier." In Festskrift till Anders Agell, edited by Torgny, Håstad, Per-Henrik Lindblom and Åke Saldéen, 193-207. Uppsala: lustus förlag.

Hambre, Anna-Maria: 2015. Tax Confidentiality. A Comparative Study and Impact Assessment of Global Interest. Örebro: Örebro Studies in Law 6. Örebro University.

Knops, Mick, Schaper, Marcel GH. 2014. "Holding complexity: analysing the CJEU's VAT case law as a network". World Journal of VAT/GST Law 3 [3]: 141-65

Lang, Michael, Ecker, Thomas. 2011. The Future of Indirect Taxation. Recent Trends in VAT and GST Systems Around the World. The Netherlands, Alphen aan den Rijn: Wolters Kluwer

Lang, Michael, Lejune, Ine. 2014. Improving VAT/GST Designing a Simple and Fraud Proof Tax System. The Netherlands, Amsterdam: IBFD
Lang, Michael, Melz, Peter, Kristoffersson, Eleonor. 2009. Value Added Tax and Direct Taxation. Similarities and Differences. The Netherlands, Amsterdam: IBFD

Legrand, Pierre. 1997. "The Impossibility of Legal Transplants". Maastricht Journal of European and Comparative Law [4]:111-24.

Pound, Roscoe. 1928. "Comparative law in the formation of Amarican common law". In Actorum acadmiae universalis iurisprudentiae comparativae (volume 1), edited by Elemér Balough, 183-97. Berlin: Hermann Sack Verlag.

Rainer Michael. 2010. Introduction to Comparative Law. Wien: MANZsche Verlags- und Universitätsbuchhandlung.

Rendahl, Pernilla. 2008. Cross-Border Consumption Taxation of Digital Supplies. A Comparative Study of Double Taxation and Unintentional Non-Taxation of B2C E-Commerce. Jönköping: JIBS Dissertation Series No. 052. Jönköping University.

Rizal Salim, Mohammed. 2009. "Are legal transplants impossible?" Journal of Comparative Law. 182-91.

Sacco, Rudolfo. 1991. "Legal formants: A Dynamic Approach to Comparative Law”. The American Journal of Comparative Law. 39 [1]: 1-34.

Shenk, Alan, Oldman, Oliver. 2007. Value Added Tax - A comparative approach. Cambridge: Cambridge Law Series.

Thuronyi, Victor. 2003. Comparative Tax Law. The Netherlands, Alphen aan den Rijn: Wolters Kluwer.

Watson, Alan. 2008. Comparative law: Law, Reality and Society $\left(2^{\text {nd }}\right.$ edition). USA, Lake Mary: Vandeplas Publishing.

Watson, Alan. 1974. Legal transplants: An approach to comparative law, Virginia: University Press of Virginia

Watson, Alan. 2000. "Legal Transplants and European Private law", E.J.C.L 4[4] December 2000, http://www.ejcl.org/44/art44-2.html

Wiman, Bertil. 2005. “Att jämföra rätt”. In Festskrift till Nils Mattsson. edited by Kristina Ståhl and Per Thorell. 503-13. Uppsala: lustus förlag.

Zweigert, Konrad 1972. "Methodological problems in comparative law". Israel Law Review: [7] 765-74

Zweigert, Konrad, Kötz, Hein. 1998. An introduction to comparative law $\left(3^{\text {rd }}\right)$. Oxford: Clarendon Press. 